\title{
Validation of models for predicting milk urea nitrogen concentrations*
}

\author{
P.M. Meyer ${ }^{1}$, P.F. Machado ${ }^{2}$, A. Coldebella ${ }^{3}$, C.H. Corassin ${ }^{2}$, \\ L.D. Cassoli ${ }^{2}$, K.O. Coelho ${ }^{4}$ and P.H.M. Rodrigues ${ }^{5}$ \\ ${ }^{I}$ Brazilian Institute of Geography and Statistics/IBGE, Brazil \\ ${ }^{2}$ Agricultural College "Luiz de Queiroz", University of Sao Paulo/USP, Brazil \\ ${ }^{3}$ Brazilian Centre of Agriculture and Animal Research/EMBRAPA - Suinos e Aves, Brazil \\ ${ }^{4}$ Veterinary College, Federal University of Goias/UFG, Brazil \\ ${ }^{5}$ Veterinary Medicine and Animal Science College, University of Sao Paulo/USP, Brazil
}

\begin{abstract}
The objective of this study was to validate three different models for predicting milk urea nitrogen. 4.749 observations from 855 cows were used. Milk production, body weight, days in milk and lactation number were recorded at milk sampling. Milk was sampled monthly for milk composition analysis. To evaluate the models, they were tested for accuracy, precision and robustness. Model 2 (Kauffman and St-Pierre, 2001) despite being more accurate, was less precise than model 3 (Kauffman and St-Pierre, 2001), while model 1 (Jonker et al., 1998) was the least accurate and the least precise. Models were not robust.
\end{abstract}

KEY WORDS: dairy cow, MUN, nitrogen excretion, protein utilization

\section{INTRODUCTION}

Milk urea nitrogen (MUN) concentration has been used as a management tool to evaluate if a herd (or even the cows individually) has been fed with optimum quantities of protein, if the relation between rumen degraded and undegraded protein is proper and if the balance between protein and energy intake is adequate (Carlsson and Pehrson, 1994).

For this reason, mathematical models have been developed attempting to predict MUN target concentration and thus, facilitate its use in the evaluation of nutritional values of diets and in the prediction of nitrogen excreted to the

\footnotetext{
* Supported by CNPq and FAPESP, Brazil

${ }^{1}$ Corresponding author: e-mail: paulameyer@ibge.gov.br
} 
environment. In order to use them properly, they should be evaluated in the Brazilian field conditions with data from a commercial herd. This way, they may provide accurate and reliable results for predicting MUN, which was the aim of the present study.

\section{MATERIAL AND METHODS}

In the study was used 4.749 observations from 855 Holstein cows of a commercial herd (Brazil). Milk production (kg/day), days in milk (DIM), body weight $(\mathrm{BW})$ and lactation number (LN) were recorded on the milk sampling days. Seasons of the year and calving seasons were divided into summer and winter. Milk was sampled monthly for analyses of fat, protein, lactose, total solids $(\%), \operatorname{MUN}(\mathrm{mg} / \mathrm{dL})$ and somatic cell counts $\left(\times 10^{3}\right.$ cells $\left./ \mathrm{mL}\right)$. Somatic cell counts (SCC) were analysed as natural log transformation (LSCC). Fat/protein ratio (F/P) was obtained by the division of fat by protein percentage.

Animals were confined, fed 7 times/day and milked in milking parlour. They received a TMR (48\% roughage on dry matter basis) of the following composition, \%: DM 50.2, CP 16.9, NDF 31.4, nonstructural carbohydrate of DM 40.2, and $1.75 \mathrm{Mcal} / \mathrm{kg} \mathrm{DM}$ of net energy for lactation.

The models were derived from a model proposed by Jonker et al. (1998) to predict urinary nitrogen $(\mathrm{UN})$ :

$$
\mathrm{UN}=(\mathrm{NI} \times 0.83)-\mathrm{MN}-97
$$

where $\mathrm{UN}=$ excretion of urinary nitrogen (g/animal/day), NI = nitrogen intake (g/animal/day) and $\mathrm{MN}=$ nitrogen secretion in milk (g/animal/day).

To calculate UN, dry matter intake was estimated from NRC (2001) and was used for the calculation of NI. Then, UN was used to predict MUN by the following equations:

model 1: MUN = UN/12.54 (Jonker et al., 1998)

model $2:$ MUN $=$ UN/17.6 (Kauffman and St-Pierre, 2001)

model 3: $\mathrm{MUN}=\mathrm{UN} /(0.0259 \times \mathrm{BW})($ Kauffman and St-Pierre, 2001) .

To evaluate the models, they were tested for accuracy, precision and robustness. Accuracy was evaluated by the mean bias as described by Kohn et al. (1998). Precision was evaluated by the root mean square prediction error (RMSPE) (Bibby and Toutenburg, 1977) or by the residual error (Kohn et al., 1998).

To compare the models with respect to accuracy, mean bias was submitted to analysis of variance ( $F$ test) and the comparison among means was accomplished using Tukey's test (5\%). For determination of mean bias significance, i.e. if it 
differed significantly from $0, t$-test was used for mean $=0$. To compare the models for precision, residual errors were submitted to test of homogeneity of variance (Hartley's test) and compared pairwise.

Linear bias for MUN was estimated by regression of bias (predicted MUNobserved MUN) against observed MUN.

Robustness was obtained by regression of bias against selected factors. Comparison of slope coefficients was accomplished by methods of comparing two straight lines using analysis of variance (F test) and compared pairwise.

\section{RESULTS AND DISCUSSION}

According to the estimated mean biases (Table 1), model 1 overestimated MUN by $6.94 \mathrm{mg} / \mathrm{dL}$. Model 2 and model 3 overestimated MUN by 0.94 and 1.41 $\mathrm{mg} / \mathrm{dL}$, respectively. Thus, all models lacked accuracy because their mean bias differed from $0(\mathrm{P}<0.01)$.

Table 1. Mean bias (accuracy), residual error (precision), root mean square prediction error (RMSPE) and coefficient of determination $\left(\mathrm{R}^{2}\right)$, for models 1, 2 and 3, and regression of bias against observed MUN

\begin{tabular}{|c|c|c|c|}
\hline Indices & Model 1 & Model 2 & Model 3 \\
\hline Observed MUN & 13.81 & 13.81 & 13.81 \\
\hline Predicted MUN & 20.75 & 14.75 & 15.22 \\
\hline Mean bias ${ }^{1,2}$ & $6.94^{\mathrm{A} *}$ & $0.94^{\mathrm{C} *}$ & $1.41^{\mathrm{B} *}$ \\
\hline Residual error ${ }^{3}$ & $5.40^{\mathrm{A}}$ & $4.50^{\mathrm{B}}$ & $4.11^{\mathrm{C}}$ \\
\hline RMSPE $^{4}$ & 8.79 & 4.60 & 4.35 \\
\hline $\mathrm{R}^{2}$ & 0.001327 & 0.001327 & 0.007868 \\
\hline \multicolumn{4}{|c|}{ Regression of bias against observed $M U N^{5}$} \\
\hline linear bias ${ }^{6,7}$ & $-0.9540 \mathrm{~A}^{\mathrm{B}}$ & $-0.9673^{\text {В }}$ & $-0.9320^{\mathrm{A}}$ \\
\hline $\mathrm{R}^{2}$ (probability) ${ }^{8}$ & $0.3639(<0.0001)$ & $0.5378(<0.0001)$ & $0.5985(<0.0001)$ \\
\hline
\end{tabular}

${ }^{1}$ means within line, followed by different letters, differ $(\mathrm{P}<0.05)$ by Tukey's test

${ }^{2}$ probability of $t$-test for mean $=0$

* mean different from $0(\mathrm{P}<0.01)$

${ }^{3}$ residual errors within line, followed by different letters, differ by Hartley's test $(\mathrm{P}<0.05)$

${ }^{4}$ root mean square prediction error

${ }^{5}$ regression of bias (predicted MUN - observed MUN) against observed MUN

${ }^{6}$ slope coefficient of regression of bias (predicted MUN - observed MUN) against observed MUN

${ }^{7}$ means within line, followed by different letters, differ $(\mathrm{P}<0.05)$

${ }^{8}$ coefficient of determination and statistical probability of existence of slope coefficient (F test)

The models differed in precision (residual errors) so that the most precise was model 3 (4.11) and the least precise was model 1 (5.40). Thus model 2 despite being the most accurate, was intermediate precise with a residual error of 4.50 (Table 1). Model 1 was the least accurate and the least precise. 
By regressing bias against observed MUN, negative linear biases (slope coefficients) were found ( $\mathrm{P}<0.0001$; Table 1). This means that bias was the lowest when observed MUN was the highest.

Relating to robustness, the 3 models were influenced by almost all studied variables $(\mathrm{P}<0.01)$. By analysing $\mathrm{R}^{2}$, fat, total solids concentration and $\mathrm{F} / \mathrm{P}$ ratio may explain variations in the models. In addition, they also showed the highest slope coefficients.

In model 1 , body weight had a relatively high $\mathrm{R}^{2}(0.236)$, but in model $3, \mathrm{R}^{2}$ (0.0018) and the slope coefficient were low $(\mathrm{P}<0.05)$. It is important to emphasize that model 3 had already been corrected for BW. Dunlap et al. (2000) validated model 1 and observed a linear effect of BW on predicted MUN concentration, so that predicted values were higher than observed values for high BW and lower for low BW.

\section{CONCLUSIONS}

The three models for predicting MUN were different with respect to accuracy, precision and robustness. Therefore, they are of limited value when the objective is to predict MUN or to predict urinary nitrogen excretion in field conditions.

\section{REFERENCES}

Bibby J., Toutenburg H., 1977. Prediction and Improved Estimation in Linear Models. John Wiley, London, pp. 188

Carlsson J., Pehrson B., 1994. The influence of the dietary balance between energy and protein on milk urea concentration. Experimental trials assessed by two different protein evaluation systems. Acta Vet. Scand. 35, 193-205

Dunlap T.F., Kohn R.A., Dahl G.E., Erdman R.A., Varner M., 2000. The impact of bovine somatotropin, three times daily milking or extended photoperiod on nitrogen flows from dairy farms. J. Dairy Sci. 83, 968-976

Jonker J.S., Kohn R.A., Erdman R.A., 1998. Using milk urea nitrogen to predict nitrogen excretion and utilization efficiency in lactating dairy cows. J. Dairy Sci. 81, 2681-2692

Kauffman A.J., St-Pierre N.R., 2001. The relationship of milk urea nitrogen to urine nitrogen excretion in Holstein and Jersey cows. J. Dairy Sci. 84, 2284-2294

Kohn R.A., Kalscheur K.F., Hanigan M., 1998. Evaluation of models for balancing the protein requirements of dairy cows. J. Dairy Sci. 81, 3401-3414

National Research Council, 2001. Nutrient Requirements of Dairy Cattle. $7^{\text {th }}$ revised Edition. National Academy Press, Washington, DC 